\title{
Liver cirrhosis and pregnancy: a case report and review of literature
}

\author{
Veronika Zvárová1, 2, Jiří Dolina, ${ }^{1,2}$, Michal Šenkyřík', 2, Radek Kroupa ${ }^{1,2}$, Lubomíra Horňáková1, 2,

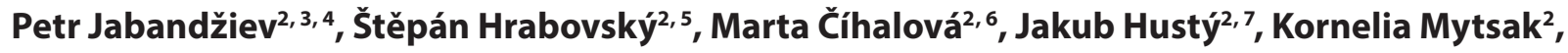 \\ Lumír Kunovský1, 2, 8 \\ 'Department of Gastroenterology and Internal Medicine, University Hospital Brno, Czech Republic \\ ${ }^{2}$ Faculty of Medicine, Masaryk University, Brno, Czech Republic \\ ${ }^{3}$ Department of Pediatrics, University Hospital Brno, Czech Republic \\ ${ }^{4}$ Central European Institute of Technology, Masaryk University, Brno, Czech Republic \\ ${ }^{5}$ Department of Hematology, Oncology and Internal Medicine, University Hospital Brno, Czech Republic \\ ${ }^{6}$ Department of Pathology, University Hospital Brno, Czech Republic \\ ${ }^{7}$ Department of Radiology and Nuclear Medicine, University Hospital Brno, Czech Republic \\ ${ }^{8}$ Department of Surgery, University Hospital Brno, Czech Republic
}

Liver cirrhosis is a chronic liver disease in which the liver tissue and the vascular beds are remodeled leading to impaired hepatic function. Portal hypertension and subsequent esophageal varices are a frequent complication of liver cirrhosis and are a cause of mortality in patients with liver cirrhosis. Pregnancy in women with liver cirrhosis is uncommon, the incidence being about 1 in 5950 pregnancies. Hepatocellular damage and the associated alteration in the metabolism of the sex hormones is thought to be responsible and leads to anovulation. In spite of all these factors, women with cirrhosis can and do become pregnant. Pregnancy is successful in most of the patients with chronic liver disease, but maternal and fetal complication rates are still high for decompensated liver cirrhosis. Portal hypertension associated with pregnancy is a high-risk situation as both pregnancy and portal hypertension share some of the hemodynamic changes. Risks of variceal bleeding and hepatic decompensation increases many fold during pregnancy. Despite the possible complications mentioned above, the maternal-fetal morbidity and mortality rates have been decreased by the current developments in hepatology, prevention of bleeding from varices with drugs and/or endoscopic variceal ligation, improvement in liver transplantation, and an increased experience in these issues.

We present a case of a 31-year-old female patient with liver cirrhosis who successfully managed pregnancy and birth without complications after the insertion of transjugular intrahepatic portosystemic shunt (TIPS). Unfortunately, 2 years after delivery, the patient developed lymphoblastic lymphoma and, despite intensive therapy for this disease, the patient died at the age of 40 . We did not find any link between liver cirrhosis and lymphoblastic lymphoma.

Key words: pregnancy, gravidity, liver, cirrhosis, varices, transjugular intrahepatic portosystemic shunt, lymphoma.

\section{Jaterní cirhóza a tĕhotenství: kazuistika a přehled literatury}

Jaterní cirhóza je chronické jaterní onemocnění, při kterém dochází k přestavbě jaterní tkáně a cévního řečiště vedoucí k poruše funkce jater. Portální hypertenze a následný vznik jícnových varixů jsou častou komplikací jaterní cirhózy a přícinou úmrtnosti u pacientů s jaterní cirhózou. Těhotenství u žen s jaterní cirhózou je vzácné, incidence je přibližně 1 z 5950 těhotenství. Důvodem je především hepatocelulární poškození a doprovodná změna metabolismu pohlavních hormonů. Přes všechny tyto faktory mohou ale ženy s jaterní cirhózou otěhotnět. Těhotenství je úspěšné u většiny pacientek s chronickým 
onemocněním jater, ale u pacientek s dekompenzovanou jaterní cirhózou můžeme očekávat vysokou míru komplikací. Portální hypertenze spojená s těhotenstvím patři mezi vysoce rizikové situace. V obou případech dochází k hemodynamickým změnám, kdy potřeby rostoucího plodu mohou dále zhoršovat portální hypertenzi a tím se zvyšuje riziko krvácení z varixů a dekompenzace jaterního onemocnění. I přes výše zmíněné možné komplikace, mateřsko-fetální morbidita a úmrtnost byla snížena současným vývojem v hepatologii, prevenci krvácení z varixů medikamentózně/endoskopickou ligací, zlepšením transplantace jater a rostoucími zkušenostmi v této problematice.

Prezentujeme př́pad 31leté pacientky s jaterní cirhózou, která po zavedení transjugulárního intrahepatického portosystemového shuntu (TIPS) úspěšně otěhotněla a těhotenství a následný porod proběhl bez komplikací. Nicméně, 2 roky po porodu, pacientka onemocněla lymfobastickým lymfomem a i přes intenzivní terapii tohoto onemocnění zemřela ve věku 40 let. Nenašli jsme žádnou souvislost mezi jaterní cirhózou a lymfoproliferativním onemocněním.

Klíčová slova: těhotenství, gravidita, játra, cirhóza, varixy, transjugulární intrahepatický portosystemový shunt, lymfom.

\section{Introduction}

Liver cirrhosis is the final stage of progressive development of various liver diseases and is associated with significant morbidity and mortality (1). Varices are a frequent complication of liver cirrhosis and a leading cause of mortality in patients with liver cirrhosis, the incidence of varices was significantly higher in patients with Child-Pugh class B/C than in those with Child-Pugh class A (35-43\% vs. 48-72\%) (1). Pregnancy is relatively rare in women with liver cirrhosis (2). Infertility is anticipated in cirrhosis because of the altered endocrine metabolism and anovulatory cycles (3-7). In pregnant women with cirrhosis, the most common and most serious complication is variceal bleeding. Due to worsening of portal hypertension because of increased circulating blood volume and the direct pressure of the gravid uterus on the inferior vena cava, impairing venous return, variceal bleeding occurs mainly during the second trimester and the in the second stage of labor (2). Pregnancy in cirrhosis carries even more risks such as higher rates of spontaneous abortion than the general population (30-40\% vs. 15-20\%), prematurity, pulmonary hypertension, splenic artery aneurysm rupture, abruption placentae, stillbirth, intrauterine growth retardation, postpartum hemorrhage and hepatic decompensation $(7,8)$. Preconceptional model for end-stage liver disease (MELD) score $\geq 10$ had $83 \%$ sensitivity and specificity for predicting liver decompensation during pregnancy (2)

The lymphoblastic lymphoma ( $\mathrm{LBL}$ ) is a rare aggressive lymphoproliferation, with B-lineage differentiation far more scarce than that of T-lineage. An estimated incidence of B-lineage LBL is about 0.1/1,000,000 annually. The overall prognosis of $L B L$ is quite favorable with about half of the patients cured by modern combined chemotherapy regimens (9).

\section{Case report}

We describe the case of a 31-year-old female patient who was admitted for primary detection of liver cirrhosis decompensation with developed hepatosplenomegaly, portal hypertension and ascites. At the hospital admission was the patient diagnosed as Child-Pugh B. Extensive ascites can be seen on computer tomography (CT) in figure 1. As part of the differential diagnosis, a transjugular liver biopsy was performed, describing chronic active hepatitis with signs of cirrhosis (Fig. 2a-d), etiologically toxonutritive. Small gastric varices unsuitable for ligation were found on the initial gastroscopy, so we
Fig. 1. Abdominal CT - contrastenhanced, transversal scan. Extensive ascites (arrows) associated with portal hypertension

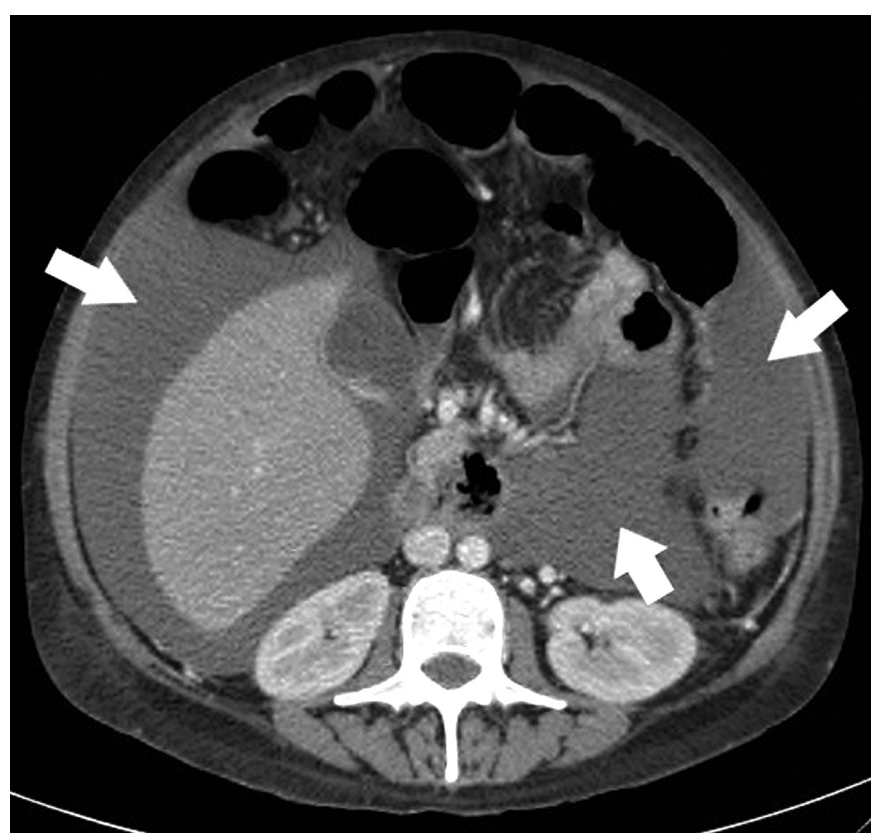

started treatment with non-selective beta-blockers. The patient gradually became stabilized and was released for home treatment. Unfortunately, the patient continued to abuse alcohol and moreover, thanks to noncompliance to therapy after half a year the patient was again acutely admitted for bleeding from the esophageal varices, solved by endoscopic ligation during urgent gastroscopy and followed by the maximum possible conservative therapy. Due to the high risk of rebleeding we indicated TIPS (transjugular intrahepatic portosystemic shunt). For impending acute on chronic liver failure we started treatment with corticosteroids. Control ultrasound and doppler of TIPS showed no sign of flow failure (Fig. 3). Subsequently, the patient underwent anti-alcohol therapy and the disease was compensated for several years with the Child-Pugh A and MELD 7 points. She visited our gastroenterology department every six months and we made an ultrasound of the TIPS and of the liver as hepatoceIlular carcinoma screening including AFP levels. Despite the irregular menstrual cycle, at 37 years of age the patient had an unexpected pregnancy. The pregnancy proceeded without complications. We made an initial endoscopy at the beginning of pregnancy without 
Fig. 2a. Image of severe steatohepatitis in the cirrhosis stage (basic HE staining, 200x): predominantly macrovesicular steatosis, confluent ballooning degeneration of hepatocytes with Mallory hyaline, focal apoptotic bodies, pronounced lobular inflammatory cellularity with predominance of neutrophil granulocytes including satellitosis, extensive perisinusoidal fibrosis and formation of fibrous septa. Ballooning degeneration with Mallory hyaline ( $\square$-green), macrovesicular steatosis ( $\square-$ red), apoptotic body $(\rightarrow$ ), satellitosis (•), perisinusoidal fibrosis (\#)

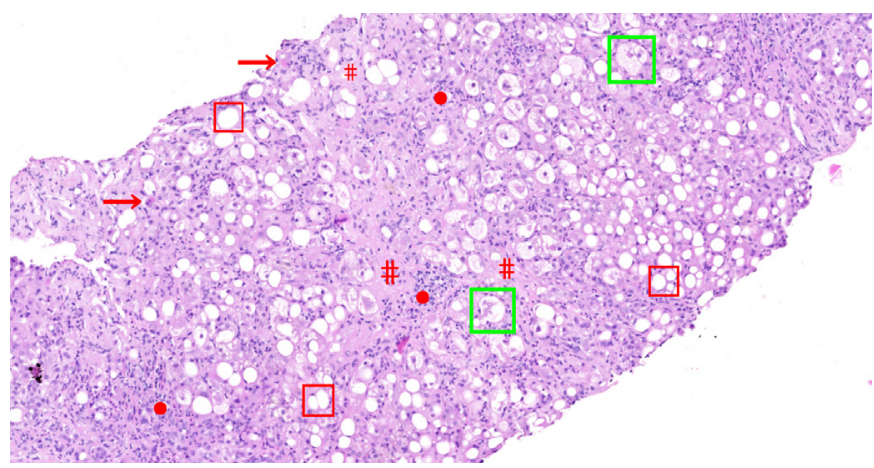

Fig. 2c. Image of severe steatohepatitis in the cirrhosis stage (van Gieson stain, 200X): porto central and porto portal fibrous septa and marked perisinusoidal fibrosis (reddish staining)

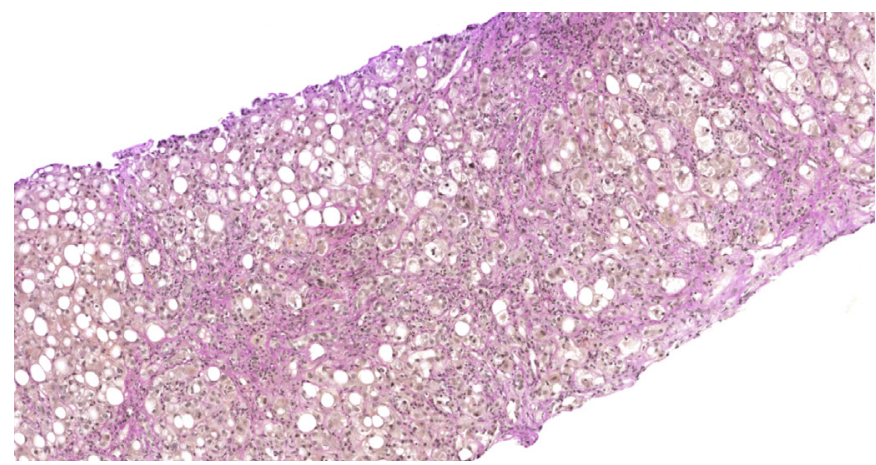

finding esophageal varices and due to this, we did not use any secondary prophylaxis. During pregnancy, the flow through the TIPS was free, without thrombosis so we did not repeat the endoscopy.

The patient gave birth to a healthy premature baby by caesarean section in the 39th week of gestation, with physiological measures $3900 \mathrm{~g}$ and $51 \mathrm{~cm}$. She came to the clinic for a check-up 4 months after delivery, liver cirrhosis was compensated, Child-Pugh A, flows in TIPS free.

One year after birth, the patient was admitted to a hospital for acutely presented paresthesia, pain and mild paresis of the right lower limb. A magnetic resonance imaging showed multiple lesions of vertebrae spanning from T6 to S2 with extraosseal infiltration of intervertebral foramens. A staging $C T$ then discovered multiple skeletal infiltrates in vertebrae, ribs, skull and limb bones and also infiltration of pancreas and breasts. Based on these findings, a biopsy of the vertebral lesion and a trephine biopsy of an iliac bone marrow were performed. Histology results then identified the lesions as an infiltration with B-lineage LBL.

Our patient was treated with several cycles of chemotherapy, however achieved only a partial remission of the bone and organ lesions and simultaneously relapsed in the central nervous system. Unfortunately, the patient died 2 years after the oncologic diagnosis.
Fig. 2b. Image of severe steatohepatitis in the cirrhosis stage (basic HE staining, 400X): predominantly macrovesicular steatosis, confluent ballooning degeneration of hepatocytes with Mallory hyaline, focal apoptotic bodies, pronounced lobular inflammatory cellularity with predominance of neutrophil granulocytes including satellitosis, extensive perisinusoidal fibrosis. Ballooning degeneration with Mallory hyaline ( $\square-$ green), macrovesicular steatosis ( $\square-$ red), apoptotic body $(\rightarrow$ ), satellitosis $(\bullet)$, perisinusoidal fibrosis (\#)

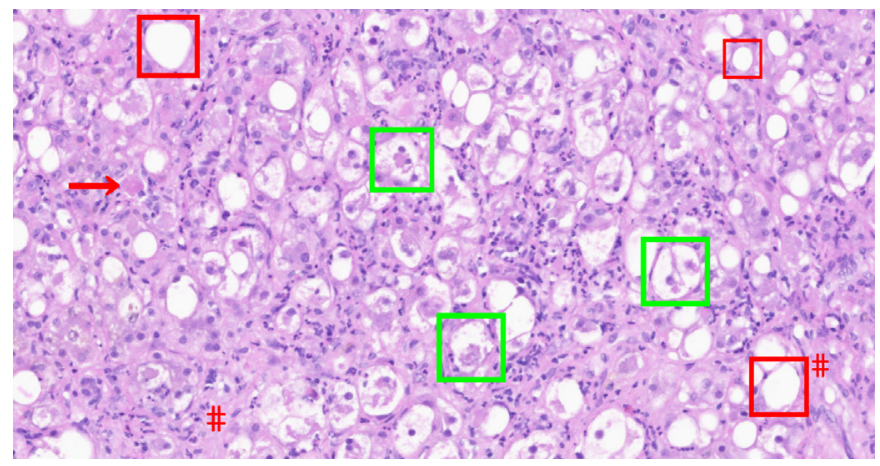

Fig. 2d. Image of severe steatohepatitis in the cirrhosis stage (van Gieson stain, 400x): marked perisinusoidal fibrosis (reddish staining)

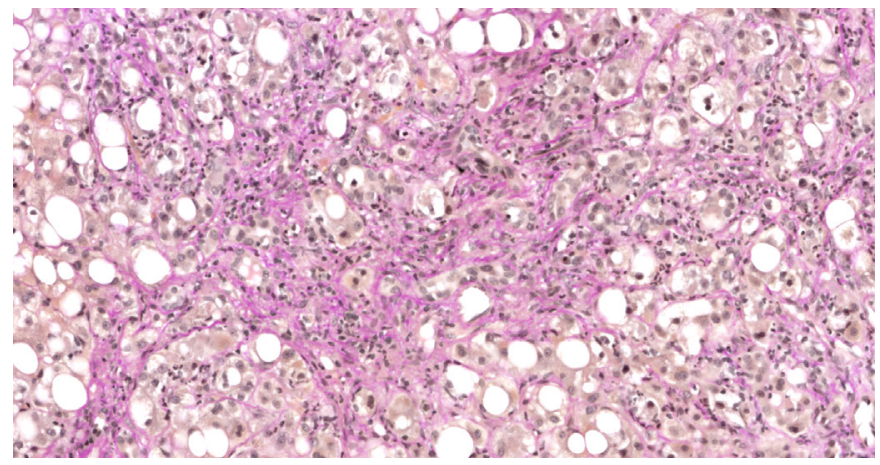

Fig. 3. Ultrasound and Doppler of the liver. After TIPS procedure - implanted stent graft with normal flow velocities around $90 \mathrm{~cm} / \mathrm{s}$

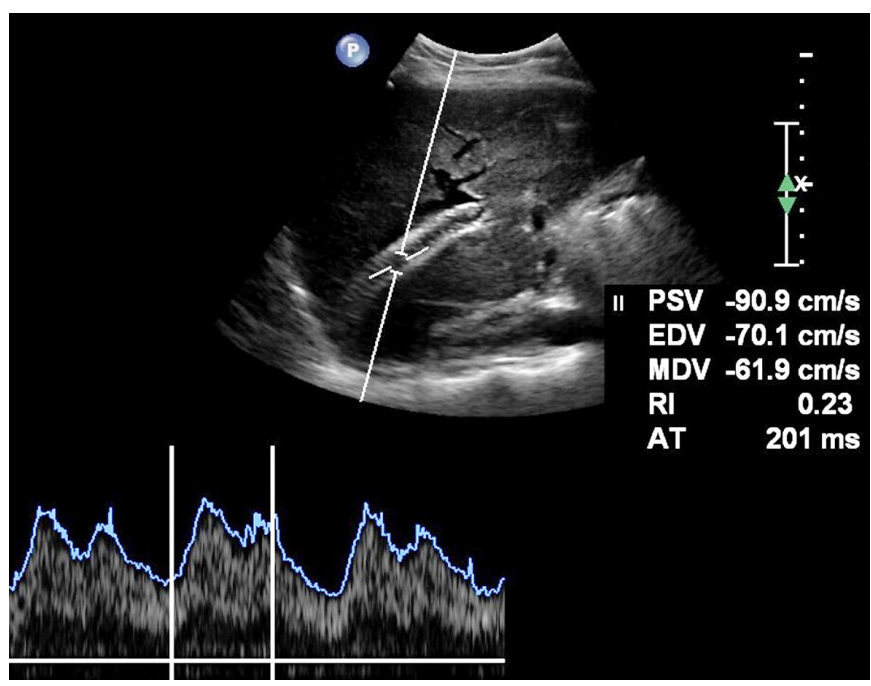

\section{Discussion}

There are no published systematic reviews on the management of cirrhosis or portal hypertension during pregnancy, which is likely because of the low prevalence of cirrhosis in women of reproductive age and reduced fertility of women with cirrhosis (10). Cirrhosis results 
in metabolic and hormonal derangements that lead to anovulation and amenorrhea presumably because of hypothalamic-pituitary dysfunction $(5,6)$. For example, hypogonadotropic hypogonadism as well as elevated levels of estrogen are seen. Hyperestrogenemia occurs due to aromatization of weak androgens from the portal circulation and consequently ovulation is prevented. Women with alcoholic hepatitis have early menopause. In alcoholic patients between 20-40 years old, decreased numbers of follicles and no corpora lutea are seen. These changes are reversible because fertility is restored after liver transplantation. Full sexual development returns within 3 years of transplant (11, 12). Successful pregnancies can be achieved in anovulatory cirrhotic patients with assisted reproductive technology. Concomitant diseases and nutritional deficiencies may also impair fertility (11).

Pregnancy is also associated with an increase in portal pressure (8). Portal hypertension develops as a result of several etiologies. Liver cirrhosis is the most common cause of portal hypertension. Other causes, like extrahepatic portal vein obstruction, non-cirrhotic portal fibrosis, portal vein thrombosis, Budd-Chiari syndrome, infection or congenital hepatic fibrosis contribute significantly to non-cirrhotic portal hypertension ( $\mathrm{NCPH}$ ). Mostly liver function is much better preserved in women with NCPH and pregnancy is spontaneous in these women (13).

Numerous hemodynamic and physiological changes occur during pregnancy. One of the earliest changes is an increase in plasma output by $40-50 \%$. Maternal cardiac output increases by $30-50 \%$ due to increase in stroke volume and the heart rate. There is a decline in systemic vascular resistance as a result of the progesterone effect and development of placental vascular beds. As a result of all of these changes, there is a profound alteration in the systemic hemodynamics, resulting in a hyperdynamic state with increased pulse pressure. These changes can worsen portal hypertension in pregnant patients with portal hypertension and significantly increase the risks of variceal hemorrhage (4). Because TIPS is a rare situation in connection with pregnancy, we cannot assess the possible effect on the placental bed. According to available literature there is limited data about patients who have had TIPS during pregnancy. No effect on TIPS patency has been reported in a few patients, but only a moderate increase in the flow velocity in the portal vein, the stent, and the hepatic artery (14).

The most common cause of maternal death in liver cirrhosis is massive upper gastrointestinal bleeding usually due to esophageal varices $(15,16)$. The risk of bleeding from varices has been estimated at 20-27\% among pregnant women with cirrhosis; however, this increases to $62-78 \%$ if esophageal varices are present $(3,6)$. The mortality rate from variceal bleeding is between $2 \%$ to $6 \%$ (5). All pregnant women with cirrhosis should have an initial screening endoscopy, which is recommended during the early second trimester or before pregnancy. Pregnant patients at risk for variceal bleed should receive primary prophylaxis, with either endoscopic variceal ligation or beta-blockers. Although there has been a reported association of beta-blockers with intrauterine growth retardation and neonatal bradycardia, nonselective beta-blocker therapy can be used as variceal bleeding prophylaxis in pregnancy (17). In women with an episode of acute variceal bleeding during pregnancy, treatment should be focused on the resuscitation and hemodynamic stabilization of the mother, antibiotic prophylaxis, and endoscopic therapy. The mainstay of treatment remains endoscopic variceal ligation (13). The use of vasopressin is not recommended during pregnancy due to the risk of arteriolar vasospasm and an increased risk of placental abruption, myocardial infarction, peripheral ischemia and hypertension. The use of octreotide is controversial (13). Third generation cephalosporins can be used for prophylaxis against spontaneous bacterial peritonitis in the event of a variceal bleed but fluoroquinolones are contraindicated in pregnancy (13). TIPS is contraindicated during pregnancy due to the risk of fetal radiation exposure. The placement is considered only if the medical treatment or the endoscopic procedures fail to control the variceal hemorrhage $(2,13)$.

Another complication in these women is hepatic decompensation leading to hepatic encephalopathy. This can occur during all stages of pregnancy but often occurs after an episode of variceal bleeding. The basis of treatment is using both lactulose and antibiotic therapy. According to available literature, the preferred antibiotic therapy is Metronidazol to Rifaximin, because Metronidazol is safer in pregnancy. Renal dialysis is the modality for hepato-renal shutdown. Terlipressin is contraindicated in pregnancy as it may exert oxytocic effect (13).

Liver transplantation is considered in patients with advanced liver disease before pregnancy. Liver transplant recipients possess an improved quality of life, their hormonal imbalance return to a normal state, ovulation resumes, and pregnancy may ensue (8). In our case, our patient's pregnancy was unplanned, so we did not consider a liver transplantation.

There is limited data about an intercurrence of alcohol-induced liver cirrhosis and lymphomas in the literature, consisting mostly of case reports (18-22). The evidence of the possible causal connection of these two diseases is thus low. Alcohol consumption is known to be a risk factor for developing cancers of the oral cavity, pharynx, larynx, esophagus, liver, colon, rectum, and female breast (23).

Alcohol consumption and the risk of lymphoid malignancies was evaluated in two large prospective cohort studies. One of the studies found a slightly increased risk of developing plasma cell neoplasms (multiple myeloma, lymphoplasmocytic lymphoma) and chronic lymphocytic leukemia in alcohol drinkers. Nevertheless, both of the studies failed to prove a statistically significant association between alcohol consumption and incidence of LBL or other aggressive lymphomas $(24,25)$.

\section{Conclusion}

Cirrhosis in pregnancy is a complex situation which requires a multidisciplinary approach. Neonatal risks are increased as well as maternal, which includes mainly bleeding (due to variceal bleed, splenic artery aneurysmal rupture, postpartum bleed) or liver failure.

We demonstrated the successful pregnancy in a 37-year-old female patient, who, despite having an irregular menstrual cycle and one episode of acute bleeding from esophageal varices in the past, managed the entire course of pregnancy without any bleeding due to TIPS. She gave birth to a healthy baby with physiological measures, 
without any complications. Unfortunately, two years later, the patient had lymphoma and despite intensive therapy for this malignant disease she died at the age of 40 .

The results of the latest studies indicate that, whilst pregnancy in women with cirrhosis is a rare event, it's becoming more common

\section{REFERENCES}

1. Hejda V. Late complications of liver cirrhosis - management of gastrointestinal bleeding in the presence of portal hypertension. Vnitř Lék. 2016; 62(Suppl2): 10-17.

2. Mikolasevic I, Filipec-Kanizaj T, Jakopcic I. et al. Liver Disease During Pregnancy: A Challenging Clinical Issue. Med Sci Monit. 2018; 24: 4080-4090.

3. Peitsidou A, Peitsidis P, Michopoulos S, et al. Exacerbation of liver cirrhosis in pregnancy: a complex emerging clinical situation. Arch Gynecol Obstet. 2009; 279: 911-913. DOI 10.1007/s00404-008-0811-4.

4. Aggarwal N, Sawnhey H, Suril V, et al. Pregnancy and Cirrhosis of the liver. Obstet Gynaecol. 1999; 39: 4: 503-506.

5. Tan J, Surti B, Saab S, et al. Pregnancy and Cirrhosis. Liver transpl. 2008; 14(8): 1081-1091. 6. Ołdakowska-Jedynak U, Jabiry-Zieniewicz Z, Pietrzak B, et al. Successful pregnancy and delivery in liver cirrhosis - a case report. E\&C Hepatology. 2012; 8(1-2): 60-62.

7. Tolunay H, Aydin M, Cim N, et al. Maternal and Fetal Outcomes of Pregnant Women with Hepatic Cirrhosis. Gastroenterol Res Pract. 2020, Article ID 5819819.

8. Hammoud Ghassan M, Almashhrawi Ashraf A, Ahmed KT, et al. Liver diseases in pregnancy: Liver transplantation in pregnancy. World J Gastroenterol. 2013; 19(43): 7647-7651. 9. Bassan R, Maino E, Cortelazzo S, et al. Lymphoblastic lymphoma: an updated review on biology, diagnosis, and treatment. Eur J Haematol. 2016; 96(5): 447-460.

10. Tran T, Ahn J, Reau N, et al. ACG Clinical Guideline: Liver Disease and Pregnancy. Am J Gastroenterol. 2016; 111: 176-194. doi: 10.1038/ajg.2015.430.

11. Davis J, Segars J, et al. Menstruation and Menstrual Disorders: Anovulation. Glob lib women's med. 2009; (ISSN: 1756-2228), DOI 10.3843/GLOWM.10296

12. Esposti SD. Pregnancy in patients with advanced chronic liver disease. Clinical Live Disease. 2014; 4: 62-68. doi:10.1002/cld.415.

13. Aggarwal N, Negi N, Aggarwal A, et al. Pregnancy with Portal Hypertension. J Clin Exp Hepatol. 2014; 4(2): 163-171.

14. Nicolas Ch, Ferrand E, d'Alteroche L, et al. Pregnancies after transjugular intrahepatic portosystemic shunt for noncirrhotic portal hypertension. Eur J Gastroenterol Hepatol. 2014; 26(4): 488-490 and the improvement in maternal and fetal care is contributing to decreased mortality.

\section{Grants or financial support:}

Supported by Ministry of Health, Czech Republic - conceptual development of research organization (FNBr, 65269705).

15. Ndububa DA, Makinde ON, Ojo OS, et al. Pregnancy in Nigerian women with liver cirrhosis: a report of three cases. Obstet case rep. 2002; 22(1): 92-94.

16. Chaudhuri K, Tan EK, Biswas A. Successful pregnancy in a woman with liver cirrhosis complicated by recurrent variceal bleeding. Obstet Case Rep. 2012; 32(5): 480-481. DOI: 10.3109/01443615.2012.683215.

17. Brady C. Liver Disease in Pregnancy: What's New. Hepatol Commun. Vol. 4, No. 2, 2020. doi.org/10.1002/hep4.1470

18. Natsuizaka M, Kudo M, Suzuki M, et al. Diffuse large B-cell lymphoma with massive portal vein tumor thrombosis in a patient with alcoholic cirrhosis: a case report and literature review. Intern Med. 2009; 48(10): 805-808.

19. Saito A, Okamoto A, Konishi M, et al. A Case of Primary Lymphoma of the Breast with Hepatic Cirrhosis. Gan To Kagaku Ryoho. 2019; 46(2): 380-382.

20. Batur A, Odev K. Primary lymphoma of the gallbladder accompanied by cirrhosis: CT and MRI findings. BMJ Case Rep. 2014; 2014: bcr2013203101.

21. Matsuda I, Okada M, Inoue T, et al. Primary follicular lymphoma of the spleen incidentally found in a patient with alcohol- and hepatitis C-related liver cirrhosis. Int J Clin Exp Pathol. 2014; 7(7): 4484-4488.

22. López R, Barrera L, Vera A, Andrade R. Concurrent liver hodgkin lymphoma and nodular regenerative hyperplasia on an explanted liver with clinical diagnosis of alcoholic cirrhosis at university hospital fundación santa fe de bogotá. Case Rep Pathol. 2014; 2014 193802. Epub 2014 Jan 5.

23. Baan R, Straif K, Grosse Y, et al. Carcinogenicity of alcoholic beverages. Lancet Oncol. 2007; 8(4): 292-293.

24. Heinen MM, Verhage BA, Schouten LJ, et al. Alcohol consumption and risk of lymphoid and myeloid neoplasms: results of the Netherlands cohort study. Int J Cancer. 2013; 133(7): 1701-1712.

25. Jayasekara H, Juneja S, Hodge AM, et al. Lifetime alcohol intake and risk of non-Hodgkin lymphoma: Findings from the Melbourne Collaborative Cohort Study. Int J Cancer. 2018; 142(5): 919-926. 